\title{
Morphology of the male agouti accessory genital glands (Dasyprocta prymnolopha Wagler, 1831) ${ }^{1}$
}

\author{
Danilo J. Ayres de Menezes², Antonio C. Assis Neto ${ }^{3}$, Moacir F. Oliveira ${ }^{4}$, \\ Maria A. Miglino ${ }^{3}$, Gabriel R. Pereira ${ }^{5}$, Carlos E. Ambrósio ${ }^{6}$, Maíra S. Ferraz ${ }^{7}$ \\ and Maria A. M. Carvalho ${ }^{7}$

\begin{abstract}
Menezes D.J.A., Assis Neto A.C., Oliveira M.F., Farias E.C., Miglino M.A., Pereira G.R., Ambrósio C.E., Ferraz MS. \& Carvalho M.A.M. 2010. Morphology of the male agouti accessory genital glands (Dasyprocta prymnolopha Wagler,1831). Pesquisa Veterinária Brasileira30(9):793-797. Departamento de Cirurgia, Universidade de São Paulo, Av. Prof. Orlando Marques de Paiva 87, São Paulo, SP 05508-270, Brazil. E-mail: antonioassis@ usp.br

The morphology of the accessory genital glands of the male agouti was studied in twenty-three animals that were raised in captivity. Twenty animals had their genital glands dissected in situ for macroscopic description. The samples of each gland were recovered, embedded in paraffin, sliced and stained by Hematoxylin-Eosin technique. It was founded four pairs of glands: the vesicular glands, the coagulating glands, the prostate and the bulbourethral glands. Histological characteristics of the vesicular, coagulating and prostate glands showed similar morphology, within the pseudostratified columnar epithelium. The tubulo-alveolartype of the bulbourethral glands showed a lack of connective tissue among the tubules, a small amount of red stained presented it the cytoplasm, and the presence of vacuoles in the tissue. This study concluded that the agouti showed to have similar morphological aspect described in the others species of rodents.
\end{abstract}

INDEX TERMS: Vesicular glands, coagulating glands, prostate gland and bulbourethral glands.

RESUMO.- [Morfologia das glândulas genitais acessórias em cutias (Dasyprocta prymnolopha Wagler, 1831).] A morfologia das glândulas genitais acessórias de cutias foram estudados em 23 animais criados em cativeiros. Vinte animais tiveram suas glândulas genitais dissecadas in situ para as descrições macroscópicas. Para o estudo

\footnotetext{
${ }^{1}$ Received on January 21, 2010.

Accepted for publication on May 6, 2010.

${ }^{2}$ Unidade Acadêmica de Medicina Veterinária, Universidade Federal de Campina Grandes (UFCG), Campus de Patos, 58700-970 Patos, PB, Brazil.

${ }^{3}$ Departamento de Cirurgia, Universidade de São Paulo (USP), Av. Prof. Orlando Marques de Paiva 87, São Paulo, SP 05508-270, Brazil. *Corresponding author: antonioassis@dracena.unesp.br

${ }^{4}$ Escola de Medicina Veterinária, Universidade Federal Rural do Semiárido, BR 110 Km 47, Mossoró, RN 59625-900, Brazil.

${ }^{5}$ Departamento de Clínica de Grandes Animais, Universidade Federal de Santa Maria (UFSM), Av. Roraima 1000, Camobi, Santa Maria, RS 97105-900, Brazil.

6 Departamento de Ciências Básicas, Faculdade de Zootecnia e Engenharia de Alimentos (FZEA), Campus da USP, Av. Duque de Caxias Norte 225, Pirassununga, SP 13535-900, Brazil.

${ }^{7}$ Departamento de Morfofisiologia Veterinária, Centro de Ciências Agrárias, Universidade Federal do Piauí (UFPI), Campus da Socopo, Teresina, PI 64049-550, Brazil.
}

microscópico foram utilizados três animais. Os fragmentos de cada glândula foram embebidos em parafina, seccionados e corados em hematoxilina e eosina. Foram encontrados quatro pares de glândulas: vesiculares, coaguladoras, próstata e bulbouretrais. As características histológicas da glândula vesicular, coaguladora e próstata mostraram morfologia similar, com epitélio colunar pseudoestratificado. O tipo tuboalveolar da glândula bulbouretral mostrou uma deficiência de tecido conjuntivo, citoplasma pouco corado e presença de vacúolos. Este estudo concluiu que a cutia apresenta as mesmas características morfológicas das glândulas genitais acessórias encontradas em roedores.

TERMO DE INDEXAÇÃO: Glândulas vesiculares, glândulas coaguladoras, próstata, glândulas bulbouretrais.

\section{INTRODUCTION}

The participation of the agouti on the environment balance and as source of animal protein for rural populations has been studied as an alternative source of commercial production that is already observed with certain frequency in some areas in Brazil (Carvalho et al. 2008). It is necessary knowledge of this species, mainly concerning the reproduc- 
tive (Rodrigues et al. 2006) and nutritional handling, is important for a more rational exploration of these animals for its preservation and production.

The specie used in this study was Drasyprocta prymnolopha that is commonly observed in humid forests of the tropical areas of Southern and Central America, varying its geographical distribution based on the species function (Alston 1876). In agouti, the first sign of puberty occur around seven months of age and sexual maturation around fourteen months (Assis-Neto et al. 2003a-e).

It has been reported that accessory genital glands of rodents are characterized by the prostate, vesicular glands, coagulating glands, the glands of the deferential ducts and bulbourethral glands with a few variations on morphology and number depending on the species (Mirand \& Shadle 1953, Ojasti 1973, Cooper \& Schiller 1975, Matamoros 1981, Hebel \& Stromberg 1986, Van Aarde \& Skinner 1986, Hillyer \& Quesenberry 1997).

Morphological studies are crucial to understand the anatomy of the male agouti that plays an important role in this species reproduction (Menezes et al. 2003). The objectives of this study were to describe the morphology of the accessory genital glands in agouti.

\section{MATERIALS AND METHODS}

Macroscopic descriptions of the accessory sex glands were described from twenty adult male agoutis (Drasyprocta prymnolopha). The animals were obtained by natural death and, fixed in $10 \%$ formalin solution in the Laboratory of Anatomy of Domestic Animals, Universidade Federal do Piauí (UFPI), Teresina, PI, Brazil. Then, the accessory genital glands were dissected in situ and morphologically described and characterized.

Three animals were used for histological study. Animals were euthanized using a drug association of acepromazine $(0.1 \mathrm{mg} / \mathrm{kg} / \mathrm{IM})$ (Acepran 1\%, Univet Indústria Veterinária S.A.) and tiletamine zolazepan (10mg/kg/IM) (Zoletil 50, Virbac Brasil Ltda, São Paulo, SP) in agreement with the protocol used at the Nucleo de Estudos e Preservação de Animais Silvestres (NEPAS), UFPI (IBAMA 02/08-618). Tissue samples of approximately $5 \mathrm{~mm}$ were collected from each gland. Fragments were fixed in Bouin solution prior to paraffin preparation and stained with Hematoxylin-Eosin method.

\section{RESULTS}

Four types of accessory genital organs of the agouti were evaluated: the vesicular glands, coagulating glands, prostate gland and bulbourethral glands (Fig.1).

The vesicular glands observed in the agouti seemed to have a tubular shape with digitiform ramification lobes. The ejaculatory duct openings at the dorsal end of the urethra are situated on the seminal colliculus together with the deferential ducts.

Histologically, the vesicular glands were constituted by relatively tightly coiled tubules and showed a layer of pseudostratified epithelium of the connective tissue intermixed with a smooth muscular layer (Fig.2A). The interstitium showed a loose conjunctive tissue layer with the presence of large veins. The capsule of this gland is formed by a thin layer of dense conjunctive tissue.

The coagulating glands of the agouti are placed to each side of the urethra and composed of lobes that emerge from the base of the vesicular glands. They seemed to be structures during the entire length with some degree of lateromedial branching and coiled medially. The coagulating glands are composed by several tubules disposed through the main duct of the longitudinal part of the vesicular glands with a convoluted surfaced shaped structure. Only the distal extremity part of the coagulating glands was visible because they were partially covered by the prostate gland and intimately adhered to the medial face of the ventral prostate (Fig.1). Their tubules run caudally reaching the urethra and draining to the prostate.

The coagulating glands showed a few large tubules sections and a thinner fibromuscular layer when compared with the vesicular glands (Fig.2B). The epithelium of the coagulating gland is characterized as a pseudostratified columnar and tends to be a higher and tightly more coiled structure than the one visible at the vesicular gland. The tubules are closely adhered to each other consequently, the interstitial and the capsule are narrower and thinner when compared to the one at the vesicular gland.

The prostate showed two equal lobes, the ventral and the dorsal lobes. The ventral lobes are located laterally to the urethra, and each one is divided into two areas, one dorsal and other ventral (Fig.1). The tubules are more convoluted than the one from the coagulating glands. However, they are still present as a tubular structure. The prostate dorsal lobes, one on each side of the urethra, present a triangular shape. They are located on the caudodorsal position to the ventral lobes, on the ventrolateral position to the rectum and their ducts open on each side of the urethra in the prostate sinus. The tubules that formed the lobes are highly more convoluted than the one from the ventral lobes, thus appearing to be a tightly coiled structure.

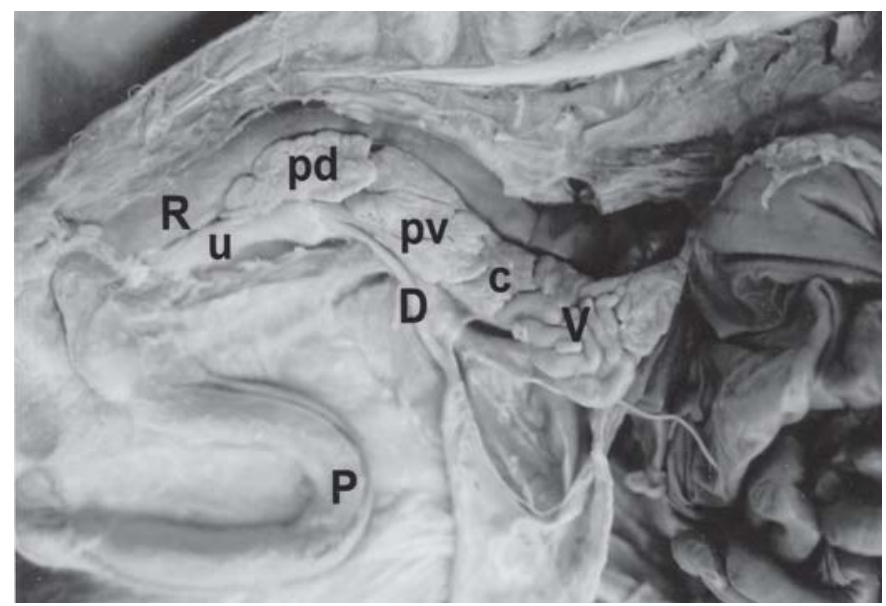

Fig.1. Sagittal section of the abdominal and pelvic cavity of the agouti. The accessory genital glands are visualized: vesicular glands (V), ventral (pv) and dorsal (pd) prostatic lobes, coagulating glands (c) and the bulbourethral glands (b). Rectum (R), penis $(P)$. 


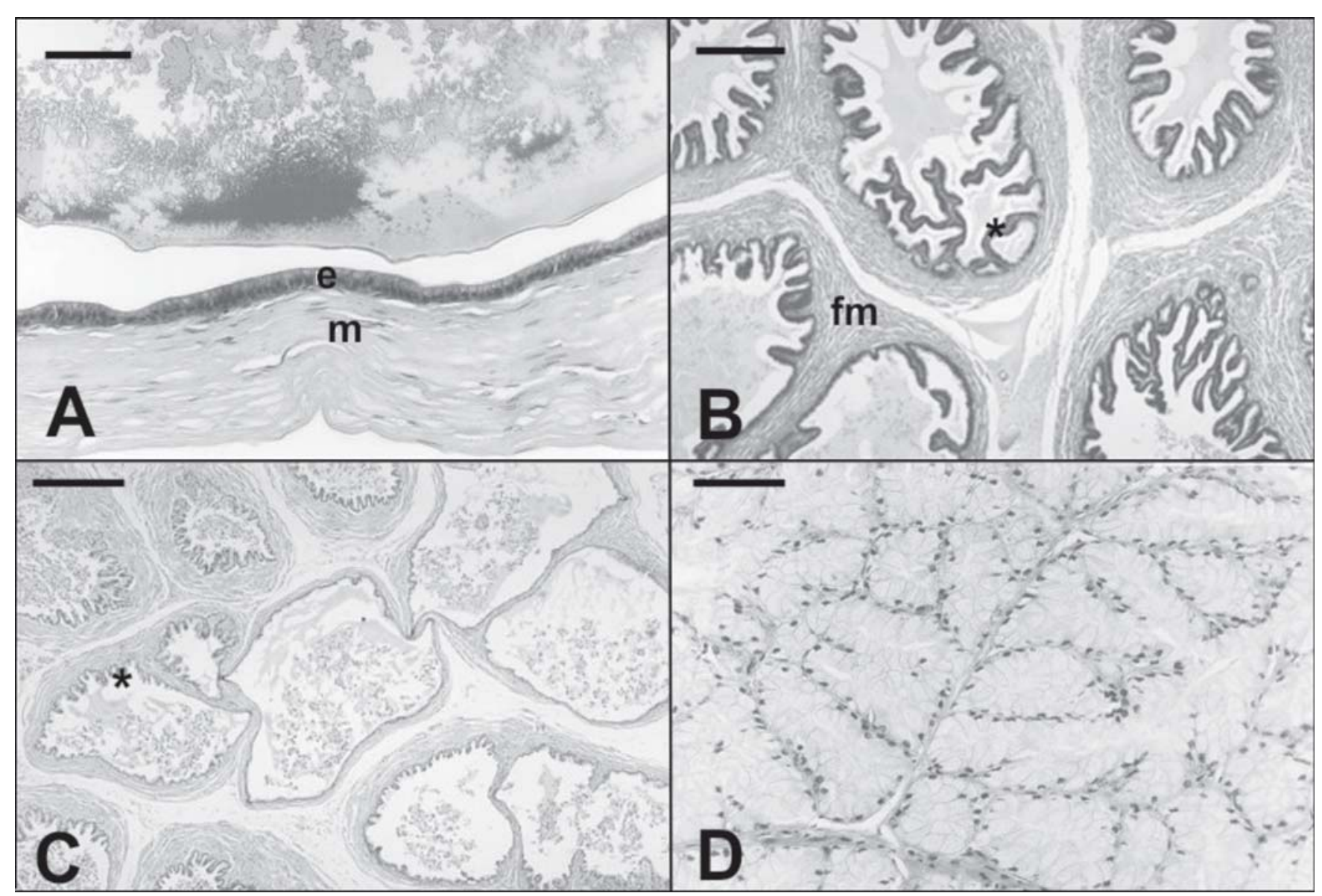

Fig.2. Agouti accessory genital glands. (A) The vesicular glands is constituted by a pseudostratified epithelium (e) on a layer of the connective tissue intermixed with a smooth muscular layer $(\mathrm{m})$. Scale Bar: $34.48 \mu \mathrm{m}$. (B) Ducts of the agouti coagulating gland showing fibromuscular tissue $(\mathrm{fm})$ and mucous membrane $\left(^{*}\right)$. Scale Bar: $170.94 \mu \mathrm{m}$. (C) Ventral lobe of prostatic gland with variation in the caliber of the ducts and fold of the mucous membrane $\left(^{*}\right)$. Bar: $170.94 \mu \mathrm{m}$. (D) Bulbourethral glands with a weak stained cytoplasm. Scale Bar: $34.48 \mu \mathrm{m}$.

The glandular tubules sections of the prostate are internally covered by a pseudostratified columnar epithelium with a variable height, and located on a thin fibromuscular layer. The interstitium is constituted of a loose conjunctive tissue with moderate amount of blood vessels and nerves. The epithelium folds and height are quite variable, like the degree of distention and gland secretion (Fig.2C).

The paired bulbourethral glands are a round shaped organ, lateromedially compressed, and covered by a thin layer of conjunctive and muscular tissue. They are located dorsolaterally to the rectum and dorsocranially to the anal sphincter muscles. These glands are dorsally covered by subcutaneous tissue that changes to superficial at the dorsal area of the base of the tail (Fig.1). The bulbourethral glands showed a single duct that penetrates in the urethra before the formation of the penis bulb. The bulbourethral glands have tubulo-alveolar shape with loose conjunctive tissue among their tubules. These glands showed a weak stained cytoplasm and presence of vacuoles, suggesting mucous secretion by mucoproteins (Fig.2D). A thick stratified skeletal tissue layer covering the gland is observed with a thin capsule of conjunctive tissue surrounding it.

\section{DISCUSSION}

The agouti accessory genital glands are composed by the prostate, vesicular glands, coagulating glands and bulbourethral glands according to the description in other rodents (Mirand \& Shadle 1953, Ojasti 1973, Cooper \& Schiller 1975, Matamoros 1981, Hebel \& Stromberg 1986, Van Aarde \& Skinner 1986, Hillyer \& Quesenberry 1997, Mollineau et al. 2008).

The vesicular glands of the agouti showed to have a tubular structure with ramifications similar to the porcupine (Hystrix africaeaustralis) (Mirand \& Shadle 1953), the capybara (Hydrochoerus hidrochaeris) (Ojasti 1973), the paca (Cuniculus paca) (Matamoros 1981), the mouse (Hebel \& Stromberg 1986) and the agouti (Dasyprocta leporina) (Mollineau et al. 2006). However, among the Hystricomorph, these glands have some variation on their shape as in agreement with other species but in general they are blinded sacks with a several diverticulums that ramify to one or to both sides of the main trunk (Weir 1974). In guinea pig (Cavia porcellus) these glands are cylindrical, prolonged and tubular (Cooper \& Schiller 1975, Hillyer \& Quesenberry 1997). In some rodents the vesicular glands are not mentioned such as in hutia 
(Capromys pilorides) (Angulo \& Alvarez 1948) and mole rats (Spalax ehrenbergi) (Gotteich et al. 1996). We observed that the ducts of each gland are jointed within the deferential ducts that end in the seminal colliculus of the urethra to form the ejaculatory ducts, this same structure is also observed in the porcupine (Mirand \& Shadle 1953) and in the guinea pig (Cooper \& Schiller 1975).

In the agouti, the vesicular glands consist of a relative large number of thick tubules, varying the membrane folds that are similar structures presented in the lesser bandicoot rat (Bandicota bengalensis) (Amiya \& Maiti 1982). The pseudostratified epithelium are observed with a layer of conjunctive tissue intermixed with loose muscular tissue, in agreement with the lesser bandicoot rat (Amiya \& Maiti 1982) and the agouti ( $D$. leporina) (Mollinaeu et al. 2008). In rabbits (Del Sol \& Vasquez 2003), the vesicular glands have three different region (cranial, medium and caudal) with a thick muscular layer. Histological characteristics of the chinchilla (Chinchilla laninger) showed variations throughout the year and they were also influenced by hormonal changes associated with photoperiod (Oróstegui et al. 2000).

The coagulating glands are peculiar in rodents, commonly referred in the male genital organs, excepted in capybara (Ojasti 1973), porcupine (Van Aarde \& Skinner 1986), and in mole rats (Spalax ehrenbergi) (Gotteich et al. 1996). However, the porcupine has a gland located between the base of the vesicular glands and the prostate that received the denomination of "X" gland (Mirand \& Shadle 1953). The agouti coagulating glands are located along the concavity base of the vesicular glands, as in agreement with the equivalent location for paca (Matamoros 1981), laboratory mouse (Gude et al. 1982, Hebel \& Stromberg 1986) and agouti (D. leporina) (Mollineau et al. 2006). In contrast, the coagulating glands from the lesser bandicoot rat (Amiya \& Maiti 1982) are located medially to the vesicular glands (Cooper \& Schiller 1975). The histological aspect of the agouti coagulating glands resembles the vesicular glands showing small tubules with a thin fibromuscular layer as described in the lesser bandicoot rat (Amiya \& Maiti 1982).

The coagulating glands in the agouti have a prolonged and flat shape, with parallel tubules ending in the urethra. However, this shape is not found in guinea pig which shows a pyramidal and lobulated shape that ends in the urethra through a single duct (Cooper \& Schiller 1975). In paca, the coagulating glands are showed to have a coil shaped tubule structure (Matamoros 1981).

The prostate of agouti seemed to have a division, similar to the one found in the guinea pig (Cooper \& Schiller 1975) and in the mouse (Gude et al. 1982). The prostate of capybara (Ojasti 1973) and chinchilla (Cepeda et al. 2006) display three equal lobules, one medial and two lateral. However, in paca is described to have a pair of lobules divided into two parts) (Matamoros 1981). The laboratory mouse showed a dorsocranial (named coagulating gland), a ventral and dorsolateral lobules (Hebel \& Stromberg 1986).

The dorsal lobe of the agouti prostate seemed to have a pyramidal shape and a prolonged ventral lobe. This last one is constituted by a parenchyma that has long tubules different from the dorsal lobe. This elongated ventral lobe gives a tubular aspect to the ventral and dorsal lobules, with variations in shape for capybara (Ojasti 1973).

The prostate ducts of agouti end in the lateral part of the ejaculatory duct opening in the urethra seminal colliculus, as in agreement with citations for porcupine (Mirand \& Shadle 1953), capybara (Ojasti 1973), guinea pig (Cooper \& Schiller 1975) and laboratory mouse (Hebel \& Stromberg 1986). However, in guinea pig, the dorsal part of the prostate ends in the urethra through several ducts, and the ventral part end through one single duct (Cooper \& Schiller 1975). In contrast, the agouti showed to have the dorsal and ventral part of the prostate inverted to the one mentioned for the guinea pig.

The prostate of agouti is similar to the vesicular and coagulating glands, but it shows different areas of pseudostratified columnar epithelium with a variable in height, like the same observed in the lesser bandicoot rat (Amiya \& Maiti 1982), laboratory mouse (Hebel \& Stromberg 1986) and sand rats (Sprando et al. 1999).

In the agouti, the bulbourethral glands are ventrocranial extended and situated along the rectum to penetrate into the urethra at the transition from the urethra pelvic to the urethra penian before portion, cranial to the bulb of the penis, the same observed in the guinea pig (Cooper \& Schiller 1975). The bulbourethral glands are described in all Hystricomorph (Weir 1974); however, these glands are not mentioned in capybara by Ojasti (1973).

The bulbourethral glands have a tubuloalveolar type in the agouti that are similar to the lesser bandicoot rat (Amiya \& Maiti 1982), mouse (Gude et al. 1982), and laboratory mouse (Hebel \& Stromberg 1986), but in the agouti ( $D$. leporine) these glands have a convoluted tubular type (Mollinaeu et al. 2008). These glands showed to have a mucous characteristic like glands with a less red stained cytoplasm, vacuolated cells, and a thick striated skeletal muscle layer (Gotteich et al. 1996). Differently from the agouti (D. Leporina), describe by Mollinaeu et al. (2006), we did not observe the ampulla of the deferent duct of the agouti studied in this research.

We conclude that the agouti seemed to have all the common glands observed in rodents; the vesicular glands, prostate, coagulating glands and bulbourethral glands. We also observed similar macro and microscopic findings of these glands when we compared them to other rodents.

Acknowledgements.- To Professor Eduardo C. Farias for histological analyses help during the study.

\section{REFERENCES}

Alston E. 1876. On the genus Dasyprocta, with description of a new species. Proc. Zoological Soc. London 4:347-352.

Amiya P. \& Maiti B.R. 1982. Quantitative studies of the accessory reproductive organs of the male bandicoot rat: $A$ common rodent pest. Anat. Anzeiger 151(5):483-495.

Angulo J.J. \& Alvarez M.T. 1948. The genital tract of the male conga hutia Capromys pilorides (Say, 1822). J. Mammalogy 29(3):277285. 
Assis-Neto A.C., Melo M.I.V., Carvalho M.A.M., Miglino M.A., Menezes D.J.A., Papa P. C. \& Kfouri-Júnior J.R. 2003a. Análise qualitativa do estabelecimento da espermatogênese em cutias (Dasyprocta aguti) criadas em cativeiros. Braz. J. Vet. Res. Anim. Sci. 40(3):180-184.

Assis-Neto A.C., Carvalho M.A.M., Melo M.I.V., Oliveira M.F. \& Mariana A.N.B. 2003b. Fases do desenvolvimento e diferenciação testicular em cutias (Dasyprocta aguti) criadas em cativeiros. Braz. J. Vet. Res. Anim. Sci. 40(Suppl.):71-79.

Assis-Neto A.C., Carvalho M.A.M., Melo M.I.V., Oliveira M.F, Almeida M.M., Miglino M.A., Papa P.C. \& Kfoury Junior J.R. 2003c. Aspectos biométricos do desenvolvimento testicular em cutias (Dasyprocta aguti) criadas em cativeiros. Braz. J. Vet. Res. Anim. Sci. 40(Suppl.):154-160.

Assis-Neto A.C., Melo M.I.V., Carvalho M.A.M., Miglino M.A., Oliveira M.F., Ambrósio C.E., Sousa S.M.M., Blasquez F.X.H., Papa P.C \& Kfoury Junior J.R. 2003d. Quantificação de células dos túbulos seminíferos e rendimento da espermatogênese em cutias (Dasyprocta aguti) criadas em cativeiro. Braz. J. Vet. Res. Anim. Sci. 40(Suppl.):175-179.

Assis-Neto A.C., Melo M.I.V., Carvalho M.A.M., Miglino M.A. \& Oliveira M.F. 2003e. Análise histométrica do desenvolvimento testicular em cutias (Dasyprocta aguti) criadas em cativeiro. Braz. J. Vet. Res. Anim. Sci. 40(Suppl.):202-208.

Cepeda R., Adaro L. \& Peñailillo P. 2006. Variaciones morfométricas de la próstata de Chinchilla laniger y de la concentración de testosterona plasmática durante un ciclo reproductivo anual. Int. J. Morphol. 29(1):89-97.

Carvalho M.A.M., Menezes D.J.A., Oliveira L.J., Oliveira M.F., Assis Neto A.C. \& Fernanda T.S. 2008. Segmentos anatomo-cirúrgicos arteriais do rim de cutias (Dasyprocta prymnolopha). Pesq. Vet. Bras. 28(5):249-252.

Cooper G. \& Schiller A.L. 1975. Anatomy of the Guinea Pig. Harvard University Press, Cambridge, Massachusetts. 403p.

Del Sol M. \& Vasquez B. 2003. Mesoscopía e histología de la glándula vesicular en el conejo (Oryctolagus cuniculus). Int. J. Morphol. 21(4):325-330.

Gotteich A., Hammel I., Yogev L. \& Terkel J. 1996. Quantitative microscopic changes in the mole rat's accessory Sex organs during an annual cycle. Anat. Rec. 246(2):231-237.
Gude W.D., Cosgrove G.E., Hirsch \& G.P. 1982. Histological Atlas of the Laboratory Mouse. Plenum Press, New York. 151p.

Hebel R. \& Stromberg M.V. 1986. Anatomy and Embriology of the Laboratory Rat. BioMed Verlag, Wörthesee. 270p.

Hillyer E.V. \& Quesenberry K.E. 1997. Ferrets, Rabbits, and Rodents: Clinical medicine and surgery. W.B Saunders Company, Philadelphia. 432p.

Matamoros Y. 1981. Anatomia e histologia del sistema reproductor del tepezcuinte (Cunicullus paca). Revta Biol. Tropic. 29(1):155-164.

Menezes D.J.A., Carvalho M.A.M., Assis-Neto A.C., Oliveira M.F., Farias E.C., Miglino M.A. \& Medeiros G.X. 2003. Morfologia dos órgãos genitais externos do macho de cutia (Dasyprocta aguti Linnaeus, 1766). Braz. J. Vet. Res. Anim. Sci. 40(Suppl.):148-153.

Mirand E. \& Shadle A. 1953. Gross anatomy of the male reproductive system of the porcupine. J. Mammalogy 34(2):210-220.

Mollineau W., Adogwa A., Jasper N., Young K. \& Garcia G. 2006. The gross anatomy of the male reproductive system of a neotropical rodent: The agouti (Dasyprocta leporina). Anat. Histol. Embriol. 35(1):47-52.

Mollineau W.M., Adogwa A.O. \& Garcia G.W. 2008. The gross and micro anatomy of the accessory sex glands of the male agouti (Dasyprocta leporina). Anat. Histol. Embryol. 38(3):204-207.

Oróstegui C., Parraguez G., Adaro L. \& Cepeda R. 2000. Cambios histológicos y morfométricos de las vesículas seminales, inducidos por variaciones estacionales, en la Chinchilla laniger (grey) en cautiverio. Revta Chilena Anat. 18(1):89-96.

Rodrigues R.F., Carter A.M., Ambrosio C.E., dos Santos T.C. \& Miglino M.A. 2006. The subplacenta of the red-rumped agouti (Dasyprocta leporina L.). Reprod. Biol. Endocrinol. 4: ARTN 31. DOI: 10.1186/ 1477-7827-4-31.

Sprando R.L., Collins T.F.X., Black T.N., Olejnik N., Rorie J.L., West L. J., Bowers J.D., Sass N. \& Robl M. 1999. Light microscopic observations on the reproductive tract of the male sand rat, Psammomys obesus. Tissue and Cell 31(1):99-115.

Van Aarde R.J. \& Skinner J.D. 1986. Reproductive biology of the Cape porcupine, Hystrix africaeaustralis. J. Reprod. Fertility 76(2):545-552.

Weir B.J. 1974. Reproductive characteristics of hystricomorfh rodents. Symp. Zoology Soc. London 34:265-446. 